\title{
Richness and diversity of Caatinga areas in different successional stages in northeastern Brazil
}

\author{
Riqueza e diversidade de áreas de caatinga em \\ diferentes estágios sucessionais no Nordeste do Brasil
}

\author{
Rinaldo Luiz Caraciolo Ferreira ${ }^{1}$, Shirley de Oliveira Silva ${ }^{2}$, \\ José Antônio Aleixo da Silva1, Mário de Andrade Lira ${ }^{3}$, \\ Francisco Tarcísio Alves Júnior ${ }^{4}$ e Ladivania Medeiros do Nascimento ${ }^{5}$
}

\begin{abstract}
Resumo
No Nordeste do Brasil, áreas convertidas em pastagens e cultivos agrícolas são frequentemente abandonadas e, por isso, a vegetação recuperada está em diferentes estágios sucessionais. O objetivo do estudo foi caracterizar a diversidade e a estrutura de áreas de vegetação de Caatinga em diferentes estágios sucessionais no Nordeste do Brasil. Foram utilizadas duas áreas: 1) área preservada, sem evidências históricas de eliminação total da vegetação para fins de cultivos agrícolas; 2) área em regeneração, anteriormente ocupada com cultivo de Opuntia ficus-indica Mill., abandonada há cerca de 30 anos. Em cada área os dados foram coletados em 12 parcelas considerando todos os indivíduos com CAP $\geq 6,0 \mathrm{~cm}$. As espécies foram classificadas conforme a síndrome de dispersão em anemocóricas, zoocóricas e autocóricas. Para avaliar a diversidade $\alpha$ foram utilizadas estimativas de riqueza, índices de Shannon, equitatividade de Pielou e de Simpson. A diversidade $\beta$ foi avaliada por meio da análise hierárquica de agrupamentos. Para análise estrutural foram estimados densidade, área basal e valor de importância (VI). A comparação entre as distribuições de diâmetros das áreas foi realizada pelo teste de Kolmogorov-Smirnov. A análise de espécies indicadoras (ISA) foi realizada para identificar a preferência de espécies por uma área. A relação da diversidade $\beta$ com as diferenças na composição de espécies e suas densidades foi analisada com o TWINSPAN. As duas áreas apresentaram diferenças significativas $(p<0,05)$ em riqueza, densidade e área basal. Não houve diferença significativa em diversidade. Observou-se a formação de dois conjuntos florísticos (40\% de dissimilaridade), que foi corroborada pelas análises TWINSPAN e ISA. A área em regeneração, após 30 anos de abandono, apresentou diversidade de espécie similar a área preservada, mas não se recuperou quanto a composição florística, riqueza de espécies, densidade e área basal. A similaridade em distribuição diamétrica entre as áreas indica que a em regeneração está recuperando sua capacidade auto regenerante.
\end{abstract}

Palavras-chave: floresta seca, estrutura, composição florística, distribuição diamétrica.

\footnotetext{
Abstract

In northeastern Brazil, areas converted for pasture and agriculture are often abandoned; therefore the recovered areas contain vegetation at different successional stages. The aim of this study was to characterize the diversity and structure of Caatinga vegetation areas with different histories of use in northeastern Brazil. Two areas were used: 1) preserved with no historical evidence of deforestation for agricultural purposes; and 2) regenerated after cultivation of Opuntia ficus-indica Mill., approximately 30 years ago. In each area, vegetation of 12 plots was collected, considering all individuals with circumference at $1.30 \mathrm{~m}$ above ground level $(\mathrm{CAP}) \geq 6.0 \mathrm{~cm}$. Collected species were classified according to dispersal strategy into the categories of anemochoric, zoochoric, and autochoric. For the analysis of a diversity, species richness, Shannon index, Pielou's evenness, and Simpson's index were used. $\beta$ diversity was evaluated using hierarchical cluster analysis. Structural analysis using density, basal area, and value of importance (VI) was conducted. A comparison between the diameter distributions of the areas was performed using the Kolmogorov-

${ }^{1}$ PhD. Professor at Department of Forestry Science. UFRPE - Universidade Federal Rural de Pernambuco. Rua Dom Manoel de Medeiros, s/n, Dois Irmãos, CEP 52171-900, Recife, PE. E-mail: rinaldo.ferreira@ufrpe.br; jaaleixo@uol.com.br.

${ }^{2}$ MSc. Professor. UNEC - Centro Universitário de Caratinga. Moacyr de Mattos, 87 - Centro - 35300-047, Caratinga, MG, Brasil. E-mail: shirleyoliveira10@yahoo.com.br.

3PhD. Researcher. IPA - Instituto Agronômico de Pernambuco. General San Martin, 1371, Bongi - 50761-000, Recife, PE. E-mail: mariolira@terra.com.br

${ }^{4} \mathrm{PhD}$. Professor at Department of Production Engineering. UEPA - Universidade do Estado do Amapá. Getúlio Vargas, 650, Central - 68900-070, Macapá, AM. E-mail: tarcisioalvesjr@yahoo.com.br.

${ }^{5} \mathrm{PhD}$. Researcher at Jardim Botânico. PCR - Prefeitura do Recife. Getúlio Vargas, s/n, BR-232, Km 14 - Curado, Recife,PE. E-mail: ladivania@hotmail.com.
} 
Smirnov test. Indicator species analysis (ISA) was conducted to identify the species preferences per area. The relationship of $\beta$ diversity with the differences in the composition of species and their densities were analyzed with TWINSPAN. The two areas showed significant differences $(p<0.05)$ in richness, density, and basal area. There was no significant difference in diversity. Cluster analysis indicated the formation of two floristic groups ( $40 \%$ dissimilarity), which was corroborated by TWINSPAN and ISA. The regenerating area after 30 years of abandonment showed similar species diversity as did the preserved area; however, floristic composition, species richness, density, and basal area did not recover. The similarity in diameter distributions between areas indicated that the abandoned area is recovering its regenerative capability.

Keywords: dry forest, structure, floristic composition, diameter distribution.

\section{INTRODUCTION}

Tropical dry forest (TDF) comprises approximately $42 \%$ of all tropical forests globally, covering areas in Africa, Australia, Central and South America, India, and Southeast Asia (QUESADA et al., 2009; LEBRIJA-TREJOS et al., 2010). TDF areas are defined as areas dominated by deciduous drought tolerant trees, growing in a climate where the average annual temperature is $\geq 25{ }^{\circ} \mathrm{C}$, and annual rainfall ranges between $700-2,000 \mathrm{~mm}$, and $\geq 3$ dry months with little or no rain (SANCHEZAZOFEIFA et al., 2005). In Brazil, approximately $70 \%$ of its northeastern region is occupied by a vegetation known as Caatinga that fits this definition (SAMPAIO, 1995; CHIANG; KOUTAVAS, 2004; PENNINGTON et al., 2009).

In many regions of the planet, TDF areas have been extensively transformed and occupied by agricultural and urban areas (MURPHY; LUGO, 1986; QUESADA et al., 2009). This is also true in the Brazilian semiarid region, where $52 \%$ of the Caatinga is comprised of secondary forests in different successional stages (PORTILLO-QUINTERO; SÁCHEZ-AZOFEITA, 2010) resulting from shifting cultivation practices that are based on deforestation, indiscriminate burning, and logging (CASTELLETTI et al., 2003).

The areas of Caatinga abandoned after exploitation have attracted the interest of researchers (PEREIRA et al., 2003; ANDRADE et al., 2005; MOREIRA et al., 2007; DANTAS et al., 2010; FERRAZ et al., 2014). However, there is no consensus on the structural characteristics of secondary vegetation areas and their potential for resilience (VASCONCELOS-SOBRINHO, 2002).

Some mechanisms and processes governing the secondary succession in TDF are already well understood (LEBRIJA-TREJOS et al., 2010). TDF contains a relatively high percentage of anemochoric species with dormant seeds, capable of regrowth (VIEIRA; SCARIOT, 2006, POORTER et al., 2010), and with a breeding period synchronized with the most favorable season for germination success (BULLOCK, 1995). In addition, compared to the tropical rain forests, mature TDFs contain fewer species, less height and basal area, fewer layers, and a simpler floristic composition (MURPHY; LUGO, 1986; SWAINE, 1992; HOLBROOK et al., 1995; SAMPAIO et al., 1998; TREJO; DIRZO; 2002). These combined factors can reduce the recovery time required after disturbance (KENNARD, 2002; LEBRIJA-TREJOS et al., 2008). However, other factors such as the history of use, the degree of isolation, and the availability of propagules are important. Furthermore, it is also known that sampling criteria used in a study could influence the estimates of the speed of recovery (LEBRIJATREJOS et al., 2010; WILLIAMS-LINERA; ALVAREZ-AQUINO, 2010).

An important issue for consideration in regeneration studies is whether the secondary forest recovers its native floristic composition and structure (CHAZDON et al., 2007). For this, the identification of areas with native plants with and without historical evidence of complete removal of vegetation is required. Therefore, for the present study, two areas in Pernambuco Agreste with known historical disturbance were included.

The present study aimed to verify if after 30 years of abandonment, an area with a history of agricultural usage can achieve a vegetative structure similar to that of preserved Caatinga areas.

\section{MATERIAL AND METHODS}

The present study was conducted at the Experimental São Bento Station, Agreste of Pernambuco, northeastern Brazil, under the ownership of the Agronomic Institute of Pernambuco-IPA, located in 
the semiarid region of Pernambuco at $08^{\circ} 31^{\prime} 56^{\prime \prime}$ south latitude (S) and $36^{\circ} 33^{\prime} 00^{\prime \prime}$ west longitude (W), and $650 \mathrm{~m}$ above sea level. The vegetation of the area is called Savanna-Steppe or "Caatinga" (IBGE, 2012).

The climate of the region, as according to Köppen's classification, is of the BSh type, which is semi-arid tropical, with a dry summer and an average annual rainfall of approximately $655 \mathrm{~mm}$, according to data obtained from the Meteorological Experimental São Bento Station.

The studies were conducted in two areas of shrub/arboreal Caatinga that were formerly continuous but are currently separated by a road of more than $3 \mathrm{~m}$ wide. The preserved areas $\left(8^{\circ} 32^{\prime} 03,1^{\prime \prime}\right.$ S $-36^{\circ} 27^{\prime} 18,1^{\prime \prime} \mathrm{W}$ and $8^{\circ} 32^{\prime} 13,8^{\prime \prime} \mathrm{S}-36^{\circ} 27^{\prime} 16,4^{\prime \prime} \mathrm{W}$ ) contain 8.9 ha of native forest with no historical evidence of complete removal of vegetation for the purpose of agriculture, as listed in records of the Experimental Station and information obtained from local residents. The area of natural regeneration $\left(8^{\circ} 32^{\prime} 16,2^{\prime \prime} \mathrm{S}-36^{\circ} 27^{\prime} 15,9^{\prime \prime} \mathrm{W}\right.$ and $\left.8^{\circ} 32^{\prime} 25,8^{\prime \prime} \mathrm{S}-36^{\circ} 27^{\prime} 18,1^{\prime \prime} \mathrm{W}\right)$ contains 9.4 ha of area previously used for forage cactus cultivation (Opuntia ficus-indica Mill.) and abandoned for nearly 30 years.

For collection of shrub and tree vegetation data, 24 plots of $20 \times 20 \mathrm{~m}, 12$ in each area, were used and distributed systematically in groups and covering areas from one extreme to another, with an interval of $30 \mathrm{~m}$ between plots in the range and $50 \mathrm{~m}$ between tracks. All individuals with a circumference at $1.30 \mathrm{~m}$ above ground level (CAP) $\geq 6.0 \mathrm{~cm}$ were tagged and numbered, and their heights were estimated according to the protocol of permanent plots measurement (COMITÊ TÉCNICO CIENTÍFICO DA REDE DE MANEJO FLORESTAL DA CAATINGA, 2007).

The botanical material was collected for preparation of herbarium specimens, after which the specimens were identified by Professors Sérgio Tavares of the Federal Rural University of Pernambuco and Dárdano de Andrade Lima of the Agronomic Institute of Pernambuco. The species were classified to the family level according to Angiosperm Phylogeny Group III (APG, 2009) and the spelling of the families was assessed with INPI (2009). The identified species were classified according to dispersal syndromes by Van Der Pijl (1982) into the categories of anemochoric (wind), zoochoric (animal), and autochoric (self) dispersion.

To determine whether the number of plots used was sufficient, the REGRELRP procedure (SAEG, 1997) was used, following the logic of the species/area curve indicating the minimum number of plots to be sampled as the point of intersection of the linear part with the plateau part.

The density parameters (ind ha-1), basal area $\left(\mathrm{m}^{2} \mathrm{ha}^{-1}\right)$, and importance value (\%) were estimated according to Mueller-Dombois and Ellemberg (1974), using the software Mata Nativa 3 (CIENTEC, 2010). The average density and basal area were the areas with a significance level ( $p$ ) equal to 5\% when compared by the Student's $t$-test (Zar, 1999) through the software R.

Two levels of diversity analysis were adopted: 1) $\alpha$ diversity (local), which refers to the number and density of species within a community (fragment); and 2) $\beta$ diversity (regional) surrounding the differences in the species composition and densities between fragments.

To assess the $\alpha$ diversity the species richness, the Shannon index, Pielou's evenness, and Simpson's index according to Magurran (1988) and Brower et al. (1997) were used. The means and their standard errors were obtained by the Jack-Knife procedure (Magurran, 1988) and the comparison of means was performed using the Mann-Whitney $U$ test with $p=0.05$ (Zar, 1999) using the software $\mathrm{R}$ after observing that they did not meet assumptions of normality and homogeneity of variance.

The $\beta$ diversity was assessed by hierarchical cluster analysis from an density array of the species in the two area plots using the Euclidean distance as a measure of dissimilarity, by the method of Ward, and PC-ORD software version 4.14 (MCCUNE; MEFFORD, 1999).

Indicator species analysis (ISA) was applied to assess the preferences of species per area (Rolstad et al., 2002) and to verify that the $\beta$ diversity among the areas relates to the differences in the composition of species and their densities, reflecting the floristic dissimilarity, as suggested by Magurran (1988), using the TWINSPAN method of classification of vegetation (Two-way Indicator Species Analysis) (KENT, COKER, 1992). After the refinement of the analysis, cut points were adopted as $0-2,2-5,5-10,10-20$ and $>100$ individuals. Eigenvalues of $>0.3$ were considered satisfactory, as recommended by Kent and Coker (1992). These analyzes were performed using PC-ORD software version 4.14 (McCune; Mefford, 1999).

For the analysis of the distribution of the diameters of individuals sampled in each community, the range of diameter class was $3 \mathrm{~cm}$. The comparison between the distributions in diameter class 
density (ind ha-1); basal area $\left(\mathrm{m}^{2} \mathrm{ha}^{-1}\right)$; species richness; and the density of species with the highest importance values, was performed by using the Kolmogorov-Smirnov test, $p=0.05$ (Sokal; Rohlf, 1995), through the R software.

\section{RESULTS AND DISCUSSION}

The number of species on the species/area curve stabilized at 3,269 and 3,496 $\mathrm{m}^{2}$ for preserved and regenerated Caatinga, respectively, corroborating that the sampling was sufficient to represent the floristic composition. In total, 39 woody species belonging to 21 families and an unidentified specimen were registered. Of these, 35 species occurred in the preserved Caatinga area and 29 in the regenerated area (Table 1). This analysis revealed three types of dispersion strategies: zoochory in $45 \%$ of the species, followed by autochory (36\%) and anemochory $(12 \%)$. Species numbering 25 shared both areas (64\% of the total). Eleven and nine species fell under Fabaceae in the preserved and regenerated areas, respectively, whereas four species in each area were Euphorbiaceae. These two families represented the majority of species ( $44 \%$ of all species, regardless of successional stage).

The proximity between preserved and regenerating areas may have been a major facilitator of dispersion and the colonization process since approximately $80 \%$ of zoochoric and autochoric species were present in the regenerating area. In areas of scrub, the ratios of dispersion syndromes were associated with decreasing precipitation and stratification of vegetation, with zoochoric dispersion being the most important during rainy periods and autochoric and anemochoric dispersion being important during dry periods (GRIZ; MACHADO, 2001; SILVA; RODAL, 2009). On the other hand, the non-predominance of anemochoric species rejects what is expected to prevail in semi-arid environments, since the anemochoric species richness is high (GRIZ; MACHADO, 2001; VIEIRA; SCARIOT, 2006; LIMA; MELO, 2015), which may be explained in the present study by the proximity of the preserved area.

The relatively preserved dry tropical and subtropical forests have an average number of 77 127 woody species ha-1 (dry forest in Costa Rica, GILLESPIE et al., 2000; deciduous dry forests in Central America, North and South, QUIGLEY; PLATT, 2003; dry forests in Central America, GRISCOM; ASHTON, 2011). These values are considerably higher than the number of species (29 sp.ha- ${ }^{-1}$ ) in areas used for agriculture (SABOGAL, 1992; GRISCOM; ASHTON, 2011). According to Sampaio (2010), typical Caatinga areas contain $<50$ woody species. Although the number of species of regenerating areas ranges from 16-45 woody species ha- ${ }^{-1}$, this depends on the history of use, inclusion criteria, and abandonment time (PEREIRA et al., 2003; ANDRADE et al., 2007; DANTAS et al., 2010). The results of the present study confirm the account of Sampaio (2010) for a preserved area and are within the range indicated for regenerating areas. However, it is noteworthy that there is no method of direct comparison between these studies and the current study. In addition, the number of species of regenerating areas depends among others on the factors mentioned, such as the combination of agents of disorder (GILLESPIE et al., 2000; KENNARD, 2002; LEBRIJA-TREJOS et al., 2008).

Although $64 \%$ of the total species are shared in both areas, the differences indicate that the regeneration over 30 years has failed to restore the flora composition of the preserved area to a natural state, thereby failing to confirm a rapid reestablishment of forests after disturbance (MURPHY; LUGO, 1986; FINEGAN, 1996; GILLESPIE et al., 2000).

The regrowth of certain tree species is an additional important mechanism of regeneration after a disturbance in TDF (MURPHY; LUGO, 1986b; VIEIRA; SCARIOT, 2006). The percentage of regeneration species with this capacity ranges between $57 \%-81 \%$, depending on the type of land use, the severity of disturbance, and successional stage (VIEIRA; SCARIOT, 2006; SAMPAIO et al., 2007).

In the study area, species with higher density values (Table 1) have this feature (for example, Aspidosperma pyrifolium, Croton argyrophyllus, Mimosa tenuiflora, Poincianella pyramidalis, Schinopsis brasiliensis, Senegalia bahiensis, and Zanthoxylum sp.), which may have contributed to the reestablishment of diversity. CORLETT (1981) and KENNARD (2002) stated that species with these skills could be considered resistant to disturbance by presenting high canopy growth rates and hence faster recovery after disturbance. 
Tabela 1. Floristic, dispersal syndromes of species, density (ind. ha-1), basal area $\left(\mathrm{m}^{2} \mathrm{ha}^{-1}\right.$ ), importance value (VI) and index indicator species (SD\%; SI\%) of the species in two areas of shrub-woody preserved Caatinga and regeneration in the Northeast of Brazil. $A=$ autochory; $Z=$ zoochory; $N A=$ anemochory; $N C=$ unclassified; SD * = indicator species of preserved Caatinga; $* *$ SI $=$ Indicator species of the Caatinga in regeneration; $\mathrm{p}=$ probability.

Table 1. Florística, síndrome de dispersão de espécies, densidade (ind. ha-1), área basal $\left(\mathrm{m}^{2} \mathrm{ha}^{-1}\right)$, valor de importância (VI) e índice de espécies indicadoras (SD\%; SI\%) das espécies em duas áreas de Caatinga arbustivo-arbórea preservada e em regeneração no Nordeste do Brasil. $\mathrm{A}=$ autocórica; $\mathrm{Z}=$ zoocória; $\mathrm{NA}=$ anemocórica; $\mathrm{NC}=$ não classificada; SD * = espécie indicadora na Caatinga preservada; SI $* *=$ espécie indicadora na Caatinga em regeneração; $p=$ probabilidade.

\begin{tabular}{|c|c|c|c|c|c|c|c|c|c|c|c|}
\hline \multirow{2}{*}{ Family } & \multirow{2}{*}{ Scientific Name } & \multirow{2}{*}{$\begin{array}{l}\text { Dis- } \\
\text { persal } \\
\text { syndro- } \\
\text { mes }\end{array}$} & \multicolumn{3}{|c|}{ Preserved Caatinga } & \multicolumn{3}{|c|}{$\begin{array}{c}\text { Caatinga in } \\
\text { Regeneration }\end{array}$} & \multirow{2}{*}{ SI } & \multirow{2}{*}{ SD } & \multirow{2}{*}{ p } \\
\hline & & & $\begin{array}{l}\text { Den- } \\
\text { sity }\end{array}$ & $\begin{array}{l}\text { Basal } \\
\text { area }\end{array}$ & VI & $\begin{array}{l}\text { Den- } \\
\text { sity }\end{array}$ & $\begin{array}{l}\text { Basal } \\
\text { area }\end{array}$ & VI & & & \\
\hline \multirow{3}{*}{ Anacardiaceae } & Myracrodruon urundeuva Allemão & $\mathrm{A}$ & 2,08 & 0,002 & 0,57 & - & - & - & 4,20 & 6,25 & 1,000 \\
\hline & Schinopsis brasiliensis Engl. & $A$ & 264,58 & 2,647 & 42,21 & 62,50 & 0,584 & 21,37 & 80,9 & 7,54 & $0,003^{*}$ \\
\hline & Spondias tuberosa Arruda & Z & 2,08 & 0,052 & 1,13 & - & - & - & 8,30 & 0,26 & 1,000 \\
\hline Apocynaceae & Aspidosperma pyrifolium Mart. & $A$ & 202,08 & 0,355 & 15,13 & 31,25 & 0,040 & 5,93 & 86,6 & 7,86 & $0,001^{*}$ \\
\hline Boraginaceae & Cordia globosa (Jacq.) Kunth & Z & 4,17 & 0,003 & 1,13 & 4,17 & 0,003 & 1,68 & 8,30 & 7,50 & 1,000 \\
\hline \multirow{2}{*}{ Capparaceae } & Capparis flexuosa (L.) L. & Z & 120,83 & 0,351 & 12,97 & 70,83 & 0,167 & 14,16 & 63,0 & 6,76 & 0,126 \\
\hline & Capparis jacobinae Moric. ex Eichler & Z & 47,92 & 0,047 & 6,22 & 12,50 & 0,020 & 4,56 & 59,5 & 8,77 & $0,043^{*}$ \\
\hline Celastraceae & Maytenus rigida Mart & Z & 8,33 & 0,009 & 1,80 & - & - & - & 25,0 & 5,90 & 0,204 \\
\hline \multirow[t]{4}{*}{ Erythroxylaceae } & Erythroxylum revolutum Mart & Z & - & - & - & 2,08 & 0,018 & 1,20 & 8,30 & 0,26 & 1,000 \\
\hline & E. subrotundum A. St. Hil & $\mathrm{Z}$ & 8,33 & 0,013 & 1,35 & - & - & - & 16,7 & 5,19 & 0,451 \\
\hline & Croton argyrophyllus Kunth & $\mathrm{A}$ & 1181,25 & 1,060 & 48,31 & 231,25 & 0,410 & 26,78 & 83,6 & 6,97 & $0,001^{*}$ \\
\hline & C. blanchetianus Baill. & A & 452,08 & 0,514 & 22,87 & 79,17 & 0,106 & 9,07 & 78,0 & 10,50 & $0,006^{*}$ \\
\hline \multirow[t]{8}{*}{ Euphorbiaceae } & C. heliotropiifolius Kunth & $\mathrm{A}$ & 6,25 & 0,005 & 0,72 & - & - & - & 8,30 & 0,26 & 1,000 \\
\hline & Jatropha mollissima Muell. Arg. & A & 33,33 & 0,040 & 5,27 & 66,67 & 0,083 & 10,04 & 38,9 & 9,32 & 0,586 \\
\hline & Sapium grandulatum (Vell.) Pax. & $\mathrm{A}$ & - & - & - & 6,25 & 0,013 & 0,86 & 16,7 & 5,55 & 0,460 \\
\hline & Bauhinia cheilantha (Bong.) Steud. & $A$ & 77,08 & 0,134 & 6,95 & 6,25 & 0,004 & 1,10 & 54,0 & 9,53 & $0,021^{*}$ \\
\hline & Caesalpinia laxiflora Mart. ex G.Don & $\mathrm{A}$ & 6,25 & 0,016 & 1,82 & - & & - & 25,0 & 5,79 & 0,223 \\
\hline & $\begin{array}{l}\text { Chloroleucon foliolosum (Benth.) J. P. } \\
\text { Lewis }\end{array}$ & $A$ & 54,17 & 0,268 & 8,34 & 39,58 & 0,088 & 8,78 & 38,5 & 7,89 & 0,545 \\
\hline & Erythrina velutina Willd. & Z & 2,08 & 0,001 & 0,56 & - & & - & 8,30 & 0,26 & 1,000 \\
\hline & Mimosa tenuiflora (Willd.) Poir. & A & 25,00 & 0,334 & 7,83 & 89,58 & 0,278 & 16,81 & 58,6 & 8,47 & 0,069 \\
\hline \multirow[t]{7}{*}{ Fabaceae } & Poincianella pyramidalis Tul. & $\mathrm{A}$ & 516,67 & 1,389 & 34,76 & 327,08 & 0,605 & 37,90 & 61,2 & 4,13 & 0,081 \\
\hline & Piptadenia stipulacea (Benth.) Ducke & A & 14,58 & 0,036 & 2,26 & - & - & - & 14,6 & 7,29 & 0,567 \\
\hline & Piptadenia viridiflora (Kunth) Benth. & $\mathrm{A}$ & 6,25 & 0,048 & 1,68 & 10,42 & 0,014 & 1,52 & 16,7 & 5,56 & 0,485 \\
\hline & Senegalia bahiensis Benth & A & 241,67 & 0,451 & 15,24 & 427,08 & 1,163 & 54,99 & 63,9 & 6,36 & $0,025^{\star *}$ \\
\hline & S. langsdorffii (Benth.) Seigler \& Ebinger & A & 89,58 & 0,329 & 9,44 & 6,25 & 0,027 & 2,29 & 54,5 & 8,99 & $0,022^{*}$ \\
\hline & S. piauhiensis (Benth.) Seigler \& Ebinger & $\mathrm{A}$ & 14,58 & 0,011 & 2,48 & - & - & - & 33,3 & 6,67 & 0,076 \\
\hline & Senna sp. & $\mathrm{NC}$ & - & - & - & 2,08 & 0,003 & 0,86 & 8,30 & 0,26 & 1,000 \\
\hline Flacourtiaceae & Prockia crucis P. Browne ex L. & Z & - & - & - & 6,25 & 0,008 & 2,59 & 25,0 & 5,81 & 0,225 \\
\hline Malpighiaceae & Ptilochaeta bahiensis Turcz & AN & 4,17 & 0,002 & 1,12 & - & - & - & 16,7 & 6,24 & 0,462 \\
\hline Meliaceae & Trichilia hirta L. & Z & 2,08 & 0,001 & 0,56 & - & - & - & 8,30 & 0,26 & 1,000 \\
\hline Myrtaceae & Não identificada & Z & 2,08 & 0,001 & 0,56 & 2,08 & 0,003 & 0,87 & 8,30 & 0,26 & 1,000 \\
\hline Nyrtaginaceae & Guapira noxia Netto Lundel & Z & - & - & - & 39,58 & 0,076 & 7,13 & 41,7 & 7,47 & $0,030^{* *}$ \\
\hline Rhamnaceae & Ziziphus joazeiro Mart & Z & 25,00 & 0,052 & 3,70 & 22,92 & 0,024 & 4,48 & 21,7 & 8,68 & 0,816 \\
\hline \multirow{2}{*}{ Rubiaceae } & Coutarea hexandra (Jacq.) K.Schum & AN & 89,58 & 0,127 & 9,18 & 37,50 & 0,073 & 7,67 & 64,6 & 7,73 & $0,023^{*}$ \\
\hline & Guettarda sp. & Z & 6,25 & 0,094 & 2,19 & 27,08 & 0,044 & 5,11 & 27,1 & 8,72 & 0,457 \\
\hline Rutaceae & Zanthoxylum sp. & Z & 68,75 & 0,129 & 8,65 & 343,75 & 0,696 & 40,01 & 76,4 & 8,24 & $0,024^{* *}$ \\
\hline Sapindaceae & $\begin{array}{l}\text { Allophylus edulis (A. St.-Hil., Cambess. } \\
\& \text { A. Juss.) Radlk. }\end{array}$ & Z & 33,33 & 0,048 & 3,87 & 27,08 & 0,053 & 7,39 & 26,1 & 8,08 & 0,904 \\
\hline Solanaceae & Não identificada & Z & 181,25 & 0,312 & 13,11 & 4,17 & 0,008 & 1,09 & 81,5 & 8,38 & $0,001^{*}$ \\
\hline Verbenaceae & Lantana camara L. & Z & 2,08 & 0,001 & 0,56 & 6,25 & 0,004 & 1,81 & 12,5 & 6,09 & 0,737 \\
\hline \multirow[t]{2}{*}{ indeterminada } & Indeterminada & $\mathrm{NC}$ & 64,58 & 0,120 & 5,48 & 2,08 & 0,001 & 0,82 & 40,4 & 8,33 & 0,047 \\
\hline & & Total & 3860,42 & 9,00 & 300 & 1993,75 & 4,62 & 300 & & & \\
\hline
\end{tabular}


Ferreira et al. - Richness and diversity of Caatinga areas in different successional stages in northeastern Brazil

Tabela 2. Results of diversity, density and basal area and standard error for two areas of Caatinga in Northeastern of Brazil.

Table 2. Resultados de diversidade, densidade e área basal e erros padrão da média para duas áreas de Caatinga no Nordeste do Brasil.

\begin{tabular}{lcc}
\hline Parameters & Preserved Caatinga & Caatinga in regeneration \\
\hline Richness (number of species) & $35 \pm 2,44 \mathrm{a}^{*}$ & $29 \pm 2,94 \mathrm{~b}$ \\
Shannon-Wiener index (H') & $2,45 \pm 0,09 \mathrm{a}^{*}$ & $2,46 \pm 0,08 \mathrm{a}$ \\
Equitability of Pielou (J) & $0,69 \pm 0,02 \mathrm{a}^{*}$ & $0,73 \pm 0,04 \mathrm{a}$ \\
Dominance Simpson (C) & $0,86 \pm 0,02 \mathrm{a}^{*}$ & $0,88 \pm 0,02 \mathrm{a}$ \\
Density (ind ha-1) & $3860,42 \pm 283,33 \mathrm{a}^{* *}$ & $1993,75 \pm 213,78 \mathrm{~b}$ \\
Basal area $\left(\mathrm{m}^{2} \mathrm{ha}^{-1}\right)$ & $9,00 \pm 0,80 \mathrm{a}^{* *}$ & $4,62 \pm 0,51 \mathrm{~b}$ \\
\hline
\end{tabular}

Means followed by the same letter do not differ at the $5 \%$ level according to Mann-Whitney test * or Student's t-test**

Médias seguidas de mesma letra não diferem ao nível de $5 \%$ conforme o teste de Mann-Whitney* ou de Student** $(p>0,05)$

However, several studies suggest that plants do not continue to coppice after a long period of repeated disturbances (BOND; MIDGLEY, 2001; SAMPAIO et al., 2007), resulting in reduced density and richness of natural regeneration. These results highlight the need for forest management in these areas to be treated with caution and to be based on reproductive strategies of the local flora.

The formation of two sets of flora occurred, whereas there was a clustering of approximately $40 \%$ (Figure 1), indicating that, at this level, the regenerating area does not regain the species composition of the preserved area. The TWINSPAN classification also generated significant divisions (eigenvalue 0.71, Figure 2). Nine and three species were identified as indicators of areas of preserved and regenerating Caatinga, respectively $(p<0.05$, Table 1$)$. These results further indicate a rapid reestablishment after disturbance, contrary to expectations by MURPHY (1986), LUGO (1986), FINEGAN (1996), and GILLESPIE et al. (2000). However, the comparison between studies should be made sparingly because the results depend on various factors and their interactions (GILLESPIE et al., 2000; KENNARD, 2002; LEBRIJA-TREJOS et al., 2008; 2010; WILLIAMS-LINERA; ALVAREZ-AQUINO, 2010).

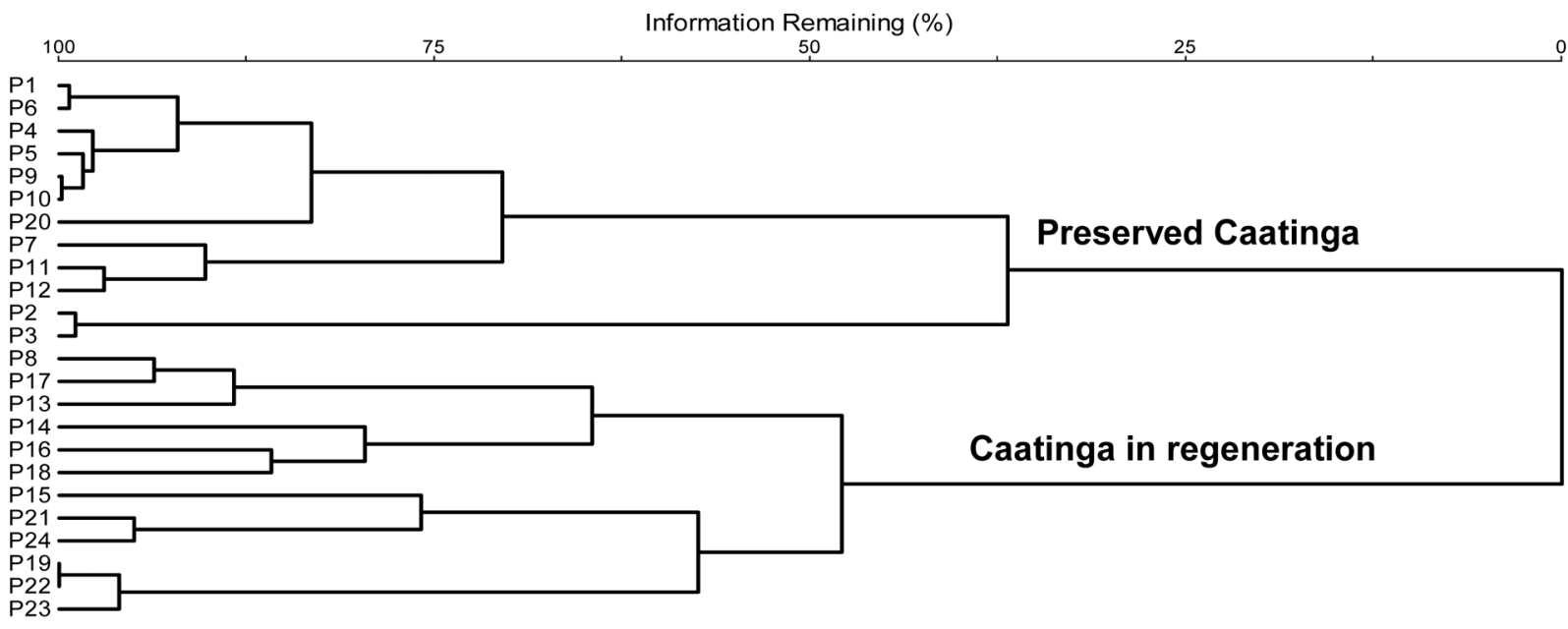

Figura 1. Floristic similarity analysis based on species density (Euclidean distance and Ward's method) between areas of preserved Caatinga (P1 -P12) and regeneration (P13 - P24) in the Northeast of Brazil.

Figure 1. Análise de similaridade florística com base na densidade das espécies (Distância Euclidiana e método de Ward) entre áreas de Caatinga preservada (P1-P12) e em regeneração (P13-P24) no Nordeste do Brasil.

Density and basal area were higher $(p<0.05)$ in preserved Caatinga $(3,860.42$ ind ha- 1 and 9 $\mathrm{m} 2 \mathrm{ha}^{-1}$ ) than in the regenerating area (1.993 ind. ha-1 and $4.62 \mathrm{~m}^{-1} \mathrm{ha}^{-1}$ ) (Table 2). Distributions of diameter classes in terms of density (Figure 3A), basal area (Figure 3B), and species richness (Figure 3C) did not differ between areas, as indicated by the Kolmogorov-Smirnov test $(p>0.05)$, demonstrating that, despite no recovery in quantitative terms in the number of individuals and basal area, the regenerating area already has a J-inverted distribution expected to uneven-aged stands (RUBIN; MANION; FABER-LANGENDOEN, 2006) and may allow self-regeneration; since regardless of succession, $80 \%$ of individuals are concentrated in the smaller diameters (diameter at breast height $(\mathrm{DBH})<5.9 \mathrm{~cm})$, suggesting that the area under regeneration can retrieve the balance between recruitment and mortality. 


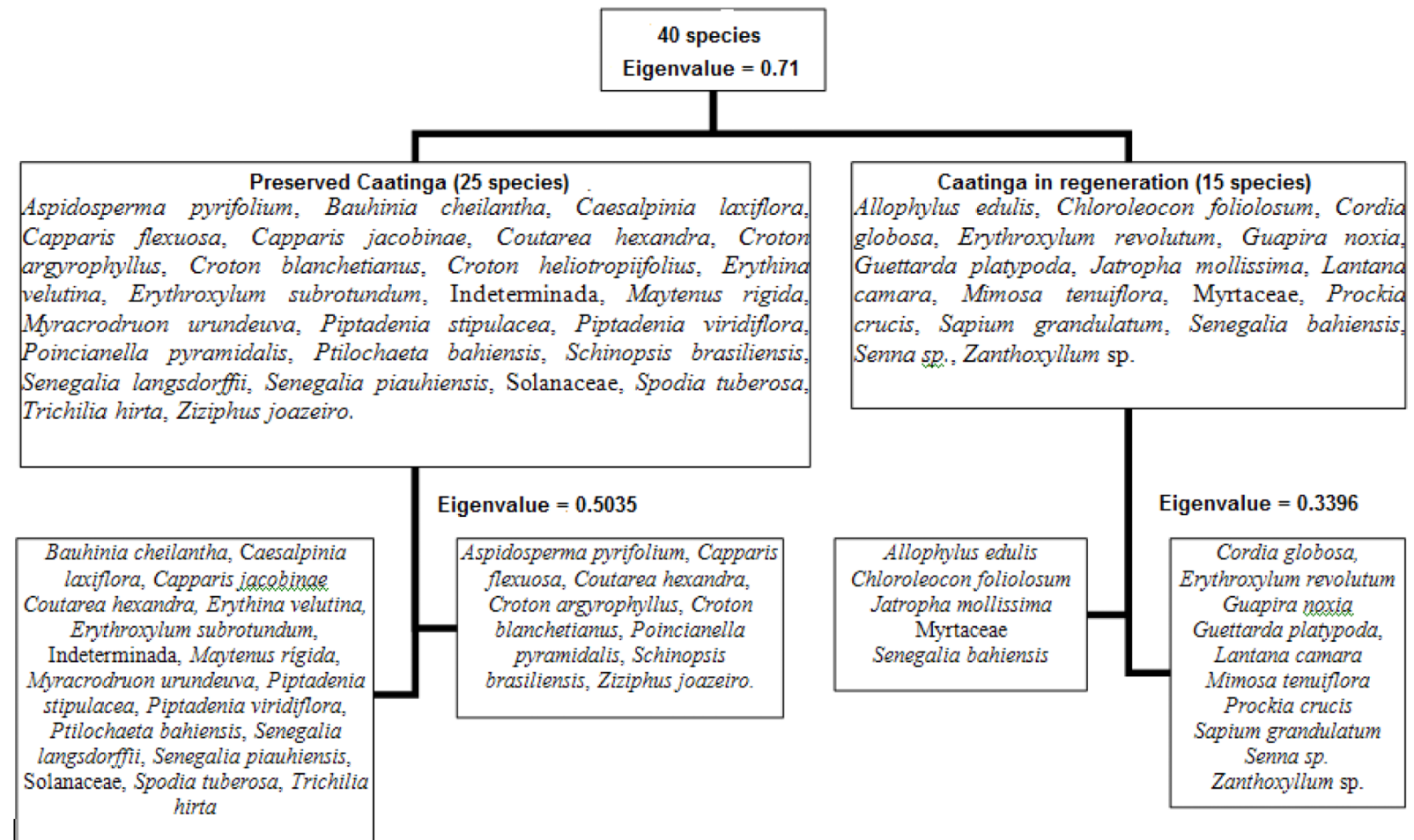

Figura 2. Classification by the TWINSPAN method of two areas of Caatinga in Northeastern of Brazil, with respective eigenvalues.

Figure 2. Classificação pelo método do TWINSPAN de duas áreas de Caatinga no nordeste do Brasil, com respectivos autovalores.

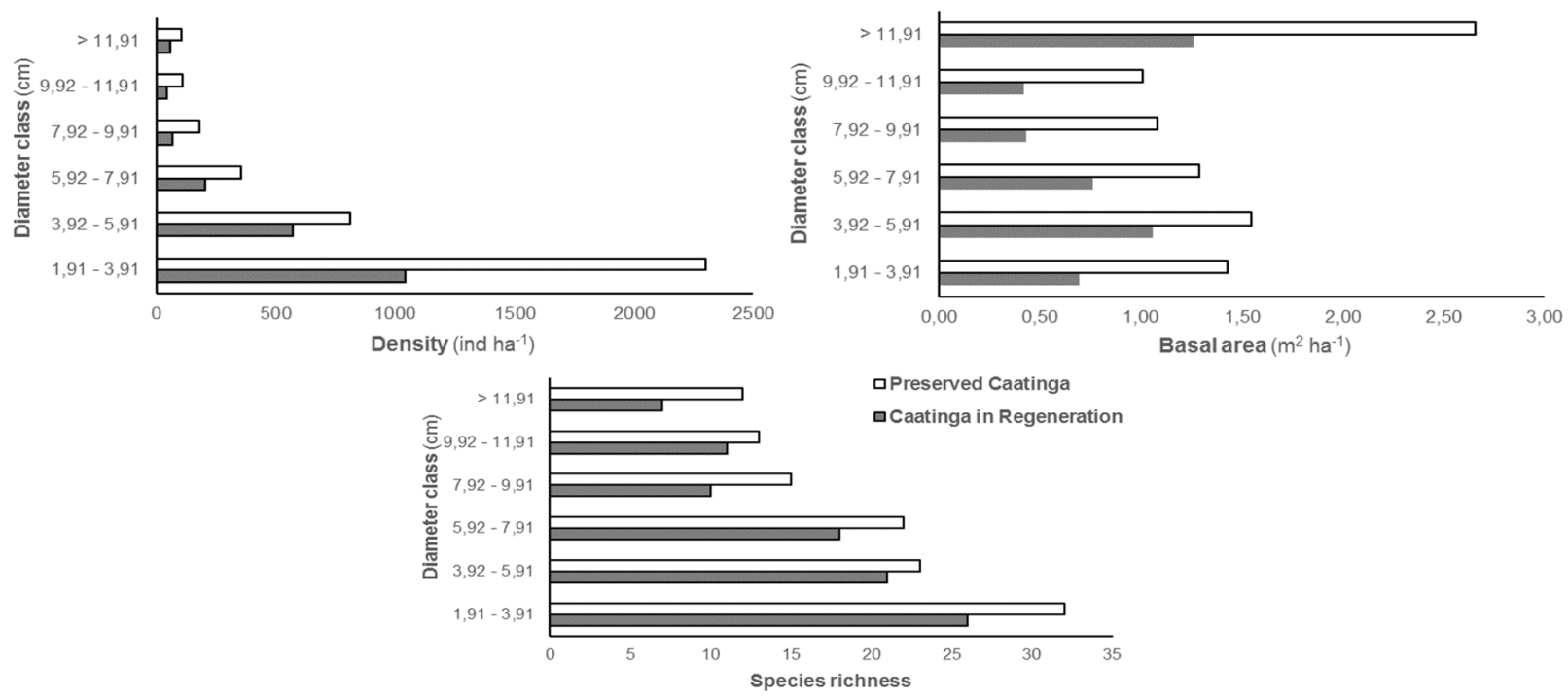

Figura 3. Density distribution (ind ha-1) and basal area $\left(\mathrm{m}^{2} \mathrm{ha}^{-1}\right)$ and species richness by diameter class ( $\mathrm{cm}$ ) in areas of preserved Caatinga and regeneration in the Northeastern of Brazil.

Figure 3. Distribuição da densidade (ind ha-1) e área basal $\left(\mathrm{m}^{2} \mathrm{ha}^{-1}\right)$ e riqueza de espécies por classe diamétrica $(\mathrm{cm})$ em áreas de Caatinga preservada e em regeneração no Nordeste do Brasil.

In both areas, only four species contributed $>50 \%$ of the value of importance. Among these, Croton argyrophyllus and Schinopsis brasiliensis contributed to the density of the preserved area and Senegalia bahiensis and Zanthoxylum sp. to the density of the regenerating area. Only Croton argyrophyllus and Poincianella pyramidalis differed significantly between areas in the distribution by diameter class. For Croton argyrophyllus, this difference was concentrated in the first three class intervals, whereas this occurred in the second and fourth class intervals for Poincianella pyramidalis (Figure 4A and B); which may be associated with differences in age of the individuals in the two areas since these species are considered as pioneer species after disturbances (PEREIRA et al., 2001) and show a more immediate response mainly by number of individuals. 
Ferreira et al. - Richness and diversity of Caatinga areas in different successional stages in northeastern Brazil
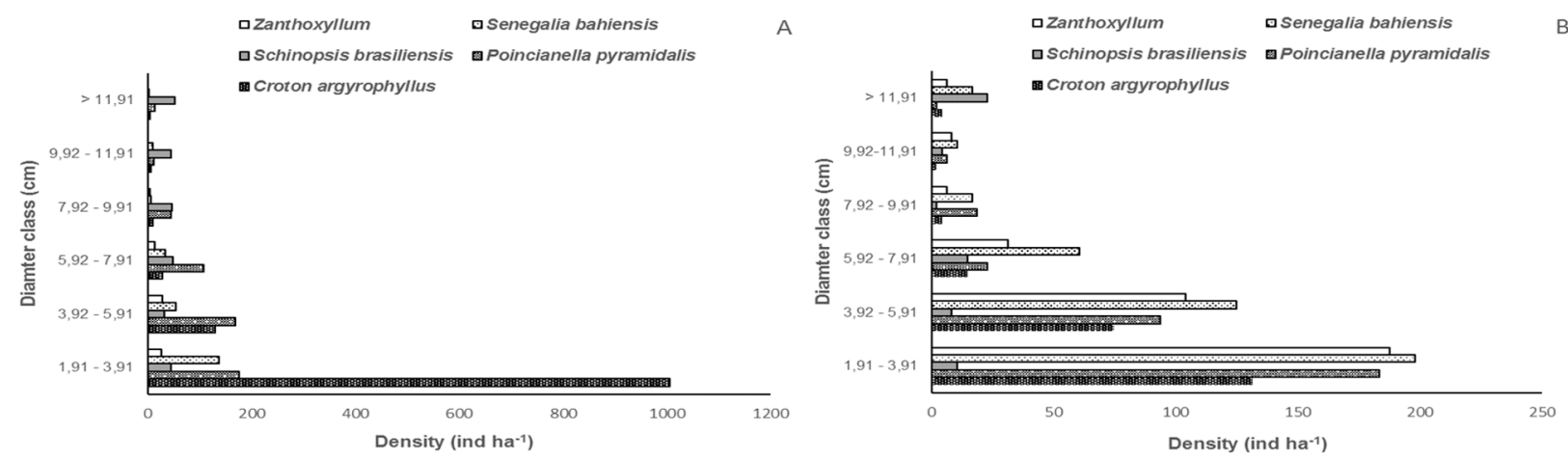

Figura 4. Density by diameter class $(\mathrm{cm})$ of the species with the highest importance value (VI) in the areas of preserved Caatinga (A) and regeneration (B) in the Northeast of Brazil (Kolmogorov-Smirnov test for species among areas, $* p>0.05)$.

Figure 4. Densidade por classe de diâmetro $(\mathrm{cm})$ das espécies com maior valor de importância (VI) das áreas de Caatinga preservada ( $A$ ) e em regeneração (B) no Nordeste do Brasil (Teste de Kolmogorov-Smirnov, por espécie entre áreas, $* \mathrm{p}>0,05)$.

The densities of the trees in the Caatinga areas were limited by less favorable conditions of (diameter at ground level $>3 \mathrm{~cm}$ ) between 1,000 and 3,000 ind ha ${ }^{-1}$ and basal area between 10 and $30 \mathrm{~m}^{2} \mathrm{ha}^{-1}$, and these estimates are heavily influenced by the inclusion criteria adopted, thereby complicating comparisons between areas (SAMPAIO, 2010). However, these values of density and basal area include those found in the study area, as well as in other areas of Caatinga of Northeastern Brazil (PEREIRA et al. 2003; ANDRADE et al. 2005; MOREIRA et al. 2007; DANTAS et al. 2010; CALIXTO; DRUMMOND, 2011; FERRAZ et al., 2014), regardless of the inclusion criteria, the successional stage, or history of vegetation usage. These results indicate that the magnitude of these values is so large that all kinds of dry vegetation can be included in the structural interval, independent of modifying variables.

The concentration of the density in a few species in the two study sites is found in TDF in general (SAMPAIO, 1995; MIZRAHI et al., 1997; BONINO; ARAÚJO, 2005; FERRAZ et al., 2014), which emphasizes the simplicity of the structure and diversity as inherent characteristics of vegetation of the semi-arid region of northeastern Brazil.

The density of Zanthoxylum sp. in the regenerating area was not expected since human interventions in the Caatinga provide for rapid establishment of pioneering species such as Croton and Mimosa genera (SAMPAIO, 2010). However, according to Hubbell (1979), the relationships between pioneering species of disturbed areas cannot be seen as predictable as they are linked to stochastic processes, as well as to the dispersion of the main mechanisms that control the arrival and density of these species in the community (HUBBELL, 2006). These observations reinforce the need for dynamic studies of communities and biology of these key species of the Caatinga so that the speed of recovery after disturbance and successional changes can be better discussed.

Differences in density and basal area of species between the two areas may indicate that, after 30 years of regeneration, no quantitative recovery of the community structure is observed, in contrast to the forecast of rapid reestablishment of dry forests after disturbance (MURPHY; LUGO, 1986). Moreover, the similar diameter distribution between two areas indicates that the recovering area is regenerating a capacity for self-regeneration. However, Quesada et al. (2009) brought attention to the fact that these forecasts were based on speculation with little empirical evidence, stating that, for more concrete conclusions regarding the speed of recovery of TDF, further detailed studies on the type of reproduction of the species and space occupation strategies (dispersion, regrowth) upon different types of disturbances and successional stages are required.

\section{CONCLUSION}

The regeneration of an area after 30 years of abandonment presented a diversity of species similar to that of the preserved area; however, species richness, density, and basal area had not yet recovered.

The floristic composition of the regeneration area differed from the preserved area.

The similarity in diameter distribution between areas indicated that the regenerating area is recovering its capacity for self-regeneration. 


\section{ACKNOWLEDGMENT}

CNPq for the scholarship the first author and productivity of the 2nd, 3rd, and 4th authors.

\section{REFERENCES}

ANDRADE, L. A.; OLIVEIRA, F.X.; NEVES, C. M. L.; FELIX, L.P. Vegetação sucessional em campos abandonados no agreste paraibano. Revista Brasileira de Ciências Agrárias, Recife, v.2, n.2, p.135-142, 2007.

ANDRADE, L.A., PEREIRA, I.M., LEITE, U.T., BARBOSA, M.R.V. Análise da cobertura de duas fitofisionomias de Caatinga, com diferentes históricos de uso, no município de São João do Cariri, estado da Paraíba. Cerne, Lavras, v.11, n.3, p.253-262, 2005.

APG III. An update of the Angiosperm Phylogeny Group classification for the orders and families of flowering plants: APG III. Botanical Journal of the Linnean Society, Southampton, v. 161, n. 2, p. 105-121, 2009.

BOND, W.J.; MIDGLEY, J.J. Ecology of sprouting in woody plants: the persistence niche. Trends in Ecology and Evolution, Cambridge, v.16, n.1, p.45-51, 2001.

BONINO, E.E.; ARAUJO. P. Structural differences between a primary and a secondary forest in the Argentine Dry Chaco and management implications. Forest Ecology and Management, Amsterdam, v.206, n.1-3, p.407-412, 2005.

BROWER, J.E.; ZARR, J.H.; von ENDE, C. N. Field and laboratory methods for general ecology. 4.ed. New York: McGraw-Hill, 1997. 288p.

BULLOCK, S.H. Plant reproduction in neotropical dry forest trees. In: BULLOCK, S.H.; MOONEY, H.A.; MEDINA, E. (Eds.). Seasonally dry tropical forests. Cambridge: Cambridge University Press, 1995. p.277296.

CALIXTO JÚNIOR, J. T.; DRUMOND, M. A. Estrutura fitossociológica de um fragmento de Caatinga sensu stricto 30 anos após corte raso, Petrolina-PE, Brasil. Revista Caatinga, Mossoró, v. 24, n. 2, p. 67-74, 2011.

CASTELLETTI, C.H.M., SILVA, J.M.C.; TABARELLI, M.; SANTOS, A.M.M. Quanto ainda resta da Caatinga? Uma estimativa preliminar. In: SILVA, J.M.C.; TABARELLI, M.; FONSECA, M.T.; LINS, L.V. (Orgs.). Biodiversidade da Caatinga: áreas e ações prioritárias para a conservação. Brasília: Ministério do Meio Ambiente, 2003. p. 91-100.

CHAZDON, R. L.; LETCHER, S. G.; van BREUGEL, M.; MARTÍNEZ-RAMOS, M.; BONGERS, F.; FINEGAN, B. Rates of change in tree communities of secondary Neotropical forests following major disturbances. Philosophical Transactions of the Royal Society B: Biological Sciences, London, v.362, n.1478, p.273-289, 2007.

CHIANG, J.C.H.; KOUTAVAS, A. Climate change: tropical flip-flop connections. Nature, London, v.432, n. 7018, p.684-685, 2004.

CIENTEC. Mata Nativa 3 - Sistema para Análise Fitossociológica, Elaboração de Inventários e Planos de Manejo de Florestas Nativas. Viçosa-MG: CIENTEC, 2010. 295p.

COMITÊ TÉCNICO CIENTÍFICO DA REDE DE MANEJO FLORESTAL DA CAATINGA. Rede de manejo florestal da Caatinga: protocolo de medições de parcelas permanentes. Recife: Associação Plantas do Nordeste. 2007. 28p.

CORLETT, R. T. Plant succession on degraded land in Singapore. Journal of Tropical Forest Science, Kepong, v. 4, n. 2, p.151-161, 1981. 
Ferreira et al. - Richness and diversity of Caatinga areas in different successional stages in northeastern Brazil

DANTAS, J. G.; HOLANDA, A. C. de; SOUTO, L. S.; JAPIASSU, A.; HOLANDA, E. M. de. Estrutura do componente arbustivo/arbóreo de uma área de Caatinga situada no município de Pombal-PB. Revista Verde, Mossoró, v. 5, n. 1, p. 134-142, 2010.

FERRAZ, J. S. F.; FERREIRA, R. L. C.; SILVA, J. A. A. da; MEUNIER, I. M. J.; SANTOS, M. V. F. dos. Estrutura do componente arbustivo-arbóreo da vegetação em duas áreas de caatinga, no município de Floresta, Pernambuco. Revista Árvore, Viçosa-MG, v.38, n.6, p. 1055-1064, 2014.

FINEGAN, B. Pattern and process in neotropical secondary rain forests: the first 100 years of succession. Trends in Ecology and Evolution, Cambrigde, v.11, n.3, p.119-124, 1996.

GILLESPIE, T.W.; GRIJALVA, A.; FARRIS, C.N. Diversity, composition, and structure of tropical dry forests in Central America. Plant Ecology, Amsterdam, v.147, n.1, p. 37-47, 2000.

GRISCOM, H.P.; ASHTON, M.S. Restoration of dry tropical forests in Central America: A review of pattern and process. Forest Ecology and Management, Amsterdam, v. 261, n.10, p. 1564-1579, 2011.

GRIZ, L. M. S.; MACHADO, I. C. S. Fruiting phenology and seed dispersal syndromes in Caatinga, a tropical dry forest in the northeast of Brazil. Journal of Tropical Ecology, Cambridge, v.17, n.2, p.303 - $321,2001$.

HOLBROOK, N.M.; WHITBECK, J.L.; MOONEY, H.A. Drought responses of neotropical dry forest trees. In: BULLOCK; S.H.; MOONEY, H.A.; MEDINA, E. (Eds.). Seasonally dry tropical forests. Cambridge: Cambridge University Press, 1995. p. 243-276.

HUBBELL, S.P. Tree dispersion, abundance and diversity in a tropical dry forest. Science, Washington, v.203, n.4387, p.1299-1309, 1979.

HUBBELL, S.P. Neutral theory and the evolution of ecological equivalence. Ecology, Washington, v.87, n.6, p. 1387-1398, 2006.

IBGE - Instituto Brasileiro de Geografia e Estatística. Manual técnico da vegetação brasileira. $2^{\text {a }}$ ed. Rio de Janeiro: IBGE; 2012. 274p.

INPI - The International Plant Names Index. Plant names. Published on the Internet http://www.ipni.org. [Accessed 01 Jan 2009].

KENNARD, D.K. Secondary forest succession in a dry tropical forest: patterns of development across a 50-year chronosequence in lowland Bolivia. Journal of Tropical Ecology, Cambrigde, v.18, n.1, p.55-66, 2002.

KENT, M.; COKER, P. Vegetation description and analysis. London: Belhaven Press, 1992. 363p.

LEBRIJA-TREJOS, E., BONGERS, F., GARCIA, E. A. P., MEAVE., J. A. Successional change and resilience of a very dry tropical deciduous forest following shifting agriculture. Biotropica, Lawrence, v.40, n.4, p:422-431, 2008.

LEBRIJA-TREJOS, E., J. A. MEAVE, L. POORTER, A. PEREZ-GARCIA, AND F. E. BONGERS. Pathways, mechanisms and predictability of vegetation change during tropical dry forest succession. Perspectives in Plant Ecology, Evolution and Systematics, Zurich, v.12, n.4, p.267-275, 2010.

LIMA, E.A., MELO, J.I.M. de. Biological spectrum and dispersal syndromes in an area of the semiarid region of north-eastern Brazil. Acta Scientiarum. Biological Science, Maringá, v.37, n.1, p.91-100, 2015.

MAGURRAN, A. E. Ecological diversity and its measurement. Princeton: Princeton University Press, 1988.

McCUNE, B., MEFFORD, M. J. PC-ORD. Multivariate analysis of ecological data. Version 4.0. Gleneden Beach: MjM Software, 1999. 
MIZRAHI, A., PRADO, J. M. R., JIMENEZ-OSORNIO, J. Composition, structure, and management potential of secondary dry tropical vegetation in two abandoned henequen plantations of Yucatan, Mexico. Forest Ecology and Management, Amsterdam, v.96, n.3, p.273-282, 1997.

MOREIRA, A. R. P., MARACAJÁ, P. B., GUERRA, A. M. N. M., SIZENANDO-FILHO, F. A., PEREIRA, T. F. C. Composição florística e análise fitossociológica arbustivo-arbóreo no município de Caraúbas-RN. Revista Verde, Mossoró, v.2, 113-126, 2007.

MUELLER-DOMBOIS, D.; ELLENBERG, H. Aims and methods of vegetation ecology. New York: John Wiley and Sons, $1974.547 \mathrm{p}$.

MURPHY, P. G.; LUGO, A. E. Ecology of tropical dry forest. Annual Review of Ecology and Systematics, Palo Alto, v. 17, p. 66-88, 1986.

MURPHY, P.G.; LUGO, A.E. Structure and biomass of a subtropical dry forest in Puerto Rico. Biotropica, Lawrence, v.18, n.2, p.89-96, 1986b.

PENNINGTON, R. T.; LAVIN, M.; OLIVEIRA-FILHO, A. Woody plant diversity, evolution, and ecology in the tropics: Perspectives from seasonally dry tropical forests. Annual Review of Ecology and Systematics, Palo Alto, v.40, p.437-457, 2009.

PEREIRA, I. M.; ANDRADE, L. A.; COSTA, J. R. M.; DIAS, J. M. Regeneração natural em um remanescente de Caatinga sob diferentes níveis de perturbação, no agreste paraibano. Acta Botânica Brasílica, São Paulo, v.15, n.3, p.431-426, 2001.

PEREIRA, I. M.; ANDRADE, L. A.; SAMPAIO, E. V. S. B.; BARBOSA, M. R. V. Use-history effects on structure and flora of Caatinga. Biotropica, Lawrence, v.35, n.2, p.154-165. 2003.

PORTILLO-QUINTERO, C.A.; SÁCHEZ-AZOFEITA, G.A.; Extent and conservation of tropical dry forests in the Americas. Biological Conservation, Boston, v.143, n. 1, p.144-155, 2010.

POORTER, L; MCDONALD, I.; ALARCÓN, A.; FICHTLER, E.; LICONA, J.C.; PEÑA-CLAROS, M.; STERCK, F.; VILLEGAS, Z. \& SASS-KLAASSEN, U. The importance of wood traits and hydraulic conductance for the performance and life history strategies of 42 rainforest tree species. New Phytologist, Lancaster, v.185, n.2, p.481-492, 2010.

QUESADA, M.; SANCHEZ-AZOFEIFA, G. A.; ALVAREZ-AÑORVE, M.; STONER, K. E.; AVILA-CABADILLA, L.; CALVO-ALVARADO, J.; CASTILLO, A.; ESPÍRITO-SANTO, M. M.; FAGUNDES, M.; FERNANDES, G. W.; GAMON, J.; LOPEZARAIZA-MIKEL, M.; LAWRENCE, D.; MORELLATO, L. P. C.; POWERS, J. S.; NEVES, F. de S.; ROSAS-GUERRERO, V.; SAYAGO, R.; SANCHEZ-MONTOYA, G. Succession and management of tropical dry forests in the Americas: Review and new perspectives. Forest Ecology and Management, Amsterdam, v.258, n.6, p.1014-1024, 2009.

QUIGLEY, M.F.; PLATT, W.J. Composition and structure of seasonally deciduous forests in the Americas. Ecological Monographs, Washington, v.73, n.1, p.87-106, 2003.

ROLSTAD, J., GJERDE, I.; GUNDERSEN, V. S.; SAETERSDAL, M. Use of indicator species to assess forest continuity: a critique. Conservation Biology, Washington, v.16, n.1, p.253-257, 2002.

RUBIN, B.D.; MANION, P.D.; FABER-LANGENDOEN, D. Diameter distributions and structural sustainability in forests. Forest Ecology and Management, Amsterdan, v.222, n.1-3, p.427-438, 2006.

SABOGAL, C. Regeneration of tropical dry forests in Central America, with examples from Nicaragua. Journal of Vegetation Science, Bethesda, v.3, n.3, p.407-416, 1992.

Sci. For., Piracicaba, v. 44, n. 112, p. 799-810, dez. 2016 DOI: dx.doi.org/10.18671/scifor.v44n112.02 
Ferreira et al. - Richness and diversity of Caatinga areas in different successional stages in northeastern Brazil

SAEG - Sistema para análises estatística e genética. Manual de uso. Viçosa: UFV; Funarbe, 1997.

SAMPAIO, E. V. S. B. Características e potencialidades. In: GARIGLIO, M. A.; SAMPAIO, E. V. S. B.; CESTARO, L. A.; KAGEYAMA, P. Y. (Orgs.). Uso sustentável e conservação dos recursos florestais da Caatinga. Brasília: Serviço Florestal Brasileiro, 2010. p. 29-48.

SAMPAIO, E. V. S. B. Overview of the Brazilian Caatinga. In: BULLOCK, S. H.; MOONEY, H. A.; MEDINA E. (Eds.). Seasonally dry forests. Cambridge: Cambridge University Press, 1995. p. 35-58.

SAMPAIO, E.V.S.B.; ARAÚJO, E.L.; SALCEDO, I.H.; TIESSEN, H. Regeneração da vegetação de caatinga após corte e queima, em Serra Talhada, PE. Pesquisa Agropecuária Brasileira, Brasília, v.33, n.5, p.621-632, 1998.

SAMPAIO, A.B., HOLL, K. D., SCARIOT, A. Regeneration of seasonal deciduous forest tree species in long-used pastures in Central Brazil. Biotropica, Lawrence, v.39, n.5, p.655-659, 2007.

SANCHEZ-AZOFEIFA, G. A.; KALACSKA, M.; QUESADA, M.; CALVO-ALVARADO, J. C.; NASSAR, J. M.; RODRÍGUEZ, J. P. Need for integrated research for a sustainable future in tropical dry forests. Conservation Biology, Washington, v.19, n.2, p.285-286, 2005.

SILVA, M.C.N.A.; RODAL, M.J.N. Padrões das síndromes de dispersão de plantas em áreas com diferentes graus de pluviosidade, PE, Brasil. Acta Botanica Brasilica, São Paulo, v.23, n.4, p.1040-1047, 2009.

SOKAL, R. R.; ROHLF, F. J. Biometry. 3.ed. New York: W.H. Freeman and Company, 1995. 887 p.

SWAINE, M. D. Characteristics of dry forests in West Africa and the influence of fire. Journal of Vegetatio Science, Washington, v.3, n.3, p.365-374, 1992.

TREJO, R. I.; DIRZO, R. Floristic diversity of Mexican seasonally dry tropical forests. Biodiversity and Conservation, Dordrecht, v.11, n.11, p.2063-2084, 2002.

VASCONCELOS SOBRINHO, J. Desertificação no nordeste do Brasil. Recife: Editora Universitária, 2002. $127 \mathrm{p}$.

VAN DER PIJL, L. Principles of dispersal in higher plants. $2^{\text {nd }}$ ed. Berlim: Springer-Verlag, 1982. 214 p.

VIEIRA, D. L. M.; SCARIOT, A. Principles of natural regeneration of tropical dry forests for restoration. Restoration Ecology, Washington, v. 14, n. 1, p. 11-20. 2006.

WILLIAMS-LINERA, G.; ALVAREZ-AQUINO, C. Tropical dry forest landscape restoration in Central Veracruz, Mexico. Ecological Restoration, Madison, v.28, n.3, p.259-261, 2010.

ZAR, J.H. Biostatistical analysis. 4.ed. New Jersey: Prentice-Hall, 1999. 633p.

Recebido em 14/05/2015

Aceito para publicação em 22/03/2016 